Eka Diana ${ }^{1}$

Moh. Rofiki ${ }^{2}$

\section{ANALISIS METODE PEMBELAJARAN EFEKTIF DI ERA NEW NORMAL}

\begin{abstract}
Abstrak
Penelitian ini bertujuan untuk menganalisis metode pembelajaran efektif di era new normal pada Madrasaha Aliyah Negeri 1 Probolinggo. Metode penelitian yang digunakan adalah studi kasus dengan jenis penelitian kualitatif deskriftif. Pengumpulan data dilakukan dengan data primer dan sekunder. Data primer diambil melalui wawancara mendalam yang dilakukan secara virtual. Sedangkan data sekunder diambil melalui dokumen dan perangkat pembelajaran seperti RPP. Sampel yang digunakan adalah 30 siswa dan 6 guru yang diambil secara purposif dengan asumsi bahwa responden tersebut sudah mewakili keseluruhan siswa dan guru dari kelas X, XI,dan XII. Teknik analisis data terdiri dari reduksi data, penyajian data, dan kesimpulan. Dari hasil analisis data dapat disimpulkan bahwa guru dapat menggunakan metode blended learning sebagai opsi dalam pembelajaran di era new normal. Dan tidak menutup kemungkinan metode daring, luring dan project based learning dapat dilaksanakan secara maksimal sesuai dengan situasi dan kondisi. Penggunaan metode pembelajaran yang tetap akan memberikan permbelajaran yang efektif.
\end{abstract}

Kata Kunci: metode pembelajaran, pembelajaran efektif, era new normal.

\begin{abstract}
This study aims to analyze effective learning methods in the new normal era at Madrasah Aliyah Negeri 1 Probolinggo. The research method used is a case study with descriptive qualitative research type. Data collection was carried out with primary and secondary data. Primary data was taken through in-depth interviews conducted virtually. Meanwhile, secondary data is taken through documents and learning tools such as lesson plans. The sample used was 30 students and 6 teachers who were taken purposively with the assumption that the respondents already represented all students and teachers from class X, XI, and XII. Data analysis techniques consist of data reduction, data presentation, and conclusions. From the results of data analysis, it can be concluded that teachers can use the blended learning method as an option in learning in the new normal era. And it does not rule out the possibility that online, offline and project based learning methods can be implemented optimally according to the situation and conditions. The use of learning methods that will continue to provide effective learning.
\end{abstract}

Keywords: learning methods, effective learning, new normal era.

\footnotetext{
${ }^{1}$ Program Manajemen Pendidikan Islam, Fakultas Agama Islam, Universitas Nurul Jadid ekadianaalwi8@gmail.com

${ }^{2}$ Program Manajemen Pendidikan Islam, Fakultas Agama Islam, Universitas Nurul Jadid mohrofiki1984@gmail.com
} 


\section{PENDAHULUAN}

Pandemin covid-19 yang melanda dunia dan Indonesia berpengaruh sangat besar, tidak hanya sektor ekonomi, transportasi dan pariwisata. Akan tetapi sektor pendidikan juga mengalami perubahan besar yang sekaligus menimbulkan pro dan kontra di masyarakat. Sejak diberlakukannya pembatasan Sosial Berskala Besar (PSBB) dalam rangka menekan penyebaran virus corona, maka semua lini kegiatan harus dihentikan. Dalam dunia pendidikan kebijakan tersebut memberikan dampak akan pelaksanaan pembelajaran yang tidak dilaksanakan secara face to face di ruang kelas, akan tetapi dengan metode pembelajaran daring (dalam jaringan) yaitu dengan pemanfaatan internet dalam pembelajaran,sehingga siswa dapat belajar kapan saja dan dimana saja (Dewi, 2020). Pembelajaran daring tidak mengharuskan guru dan siswa pergi kesekolah. Dalam pembelajaran daring penting pengusaan ilmu teknologi bagi guru agar pembelajaran tetap berjalan dengan efektif. Hakikatnya pembelajaran efektif merupakan pembelajaran yang tidak hanya berfokus kepada hasil, tetapi juga kepada proses pembelajaran sehingga pembelajaran yang bermanfaat dengan prosedur yang tepat (Yusuf, 2017;HM, 2019).

Oleh sebab itu, setiap lembaga pendidikan dituntut untuk memberikan inovasi dalam membentuk proses pembelajaran yang efektif. Tidak semua lembaga pendidikan mampu dan paham akan inovasi terbaru yang harus dipakai dalam melakukan pembelajaran selama pandemi. Kebanyakan dari lembaga tersebut belum dapat menyesuaikan dikarenakan terkendala sarana dan prasarana.

Proses pembelajaran akan terjadi manakala terdapat hubungan timbal balik antara guru dan siswa dengan lingkungannya dalam rangka mencapai tujuan pendidikan yang ditentukan. Guru sebagai ujung tombak (point central) dalam kualitas pendidikan sebagai dampak proses pembelajaran dituntut memberikan inovasi dan menggunakan metode yang tepat sehingga diperoleh pembelajaran yang maksimal, bukan hanya pembelajaran yang menitik beratkan kepada transfer knowledge akan tetapi juga transfer value (Rofiki, 2019). Penggunaan metode pembelajaran yang tepat tentunya akan membantu guru dalam proses pembelajaran, sehingga sesuai dengan tujuan pendidikan yang telah ditentukan.

Dalam era new normal, kita dipaksa untuk terus beradaptasi dengan menerapkan protokol kesehatan yang ketat yaitu 3M (mencuci tangan, memakai masker, dan menjaga jarak) yang akan menjadi kebiasan baru dalam kehidupan manusia. Bidang pendidikan yang selama ini terkesan mati suri, mulai beroperasi lagi dengan mengindahkan beberapa aturan dari pemerintah dengan tetap mematuhi protokol kesehatan (Bahri \& Arafah, 2020). Proses belajar mengajar dapat dilaksanakan dengan sesekali tatap muka dan daring.

Dari hasil observasi dan wawancara, masih banyak guru yang dalam pembelajaran selama masa pandemi dan kenormalan baru menggunakan metode pembelajaran "asal jalan". Maksudnya adalah guru menggunakan metode dalam pembelajaran semaunya saja dan cendrung asal-asalan sehingga pembelajaran tidak berjalan sebagaimana mestinya. Hal ini dapat disebabkan oleh beberapa faktor diantaranya adalah (1) masih minimnya pengetahuan akan teknologi informasi (2) belum bisa move on dari metode pembelajaran yang sebelumnya (3) kurangnya motivasi dalam pengembangan diri (4) minimnya sarana dan prasarana (5) kurangnya persiapan dalam menghadapi era ini. Berdasarkan uraian masalah di atas, maka penulis tertarik untuk meneliti metode pembelajaran yang efektif di era new normal pada Madrasah Aliyah Negeri 1 Probolinggo. 


\section{METODE}

Metode penelitian menggunakan studi kasus dengan jenis penelitian kualitatif deskriptif. Sehingga peneliti mampu mendeskripsikan metode pembelajaran efektif di era new normal ini. Pengumpulan data dalam penelitian kualitatif di lakukan dengan data primer dan data sekunder (Herdiansyah, 2010). Adapun data primer diambil melalui wawancara yang dilakukan secara virtual. Dalam penelitian ini, peneliti menggunakan wawancara mendalam yang bertujuan untuk mengumpulkan data atau informasi dengan maksud mendapatkan gambaran lengkap tentang topik yang diselidiki (Irianto, Heru dan Bungin, 2001). Sedangkan data sekunder diambil melalui dokumen penilaian, perangkat pembelajaran seperti RPP.

Sampel penelitian terdiri dari 30 siswa yang diambil secara purposif dengan asumsi bahwa 10 siswa dari masing-masing kelas X, XI, dan XII sudah mewakili keseluruhan siswa. Adapun 6 guru diambil 2 perwakilan dari masing-masing kelas, termasuk dalam responden penelitian dalam rangka memperoleh keabsahan data.

Teknik analisis data yang digunakan dalam penelitian ini menggunakan analisis kualitatif. Dalam pandangan Miles dan Hubberman terdiri dari reduksi data, penyajian data, dan kesimpulan (Sugiono, 2008).

\section{HASIL DAN PEMBAHASAN}

Metode pembelajaran merupakan cara yang dimanfaatkan oleh guru dalam rangka mengimplementasikan rencana pembelajaran yang dirancang untuk mencapai tujuan pendidikan, dengan kata metode adalah cara yang digunakan oleh guru untuk menyajikan materi kepada siswa (Indahningrum, 2020;Ulfa, Maria., 2018). Dalam memilih metode hendaknya perlu memperhatikan dan mempertimbangkan beberapa hal, yaitu: 1) tujuan yang ingin dicapai dalam pembelajaran, 2) kemampuan dan latar belakang guru, 3) kemampuan dan latar belakang siswa, 4) keadaan proses belajar berlangsung, 5) ketersedian alat atau sarana (Jamaluddin, 2015). Dalam era new normal, terdapat beberapa metode pembelajaran yang dapat digunakan antara lain yaitu 1) Project Based Learning, 2) Daring Method, 3) Luring Method, 4) Home Visit Method, dan 5) Blended Learning (Sevima, 2020).

Penelitian menghasilkan beberapa penemuan, antara lain sebagai berikut :

\section{Project Based Learning}

Metode pembelajaran ini dilakukan dengan cara membentuk kelompok belajar kecil dalam mengerjakan projek, eksperimen dan inovasi. Sebanyak 36 responden menyatakan metode pembelajaran ini sangat membantu dalam mencapai tujuan pembelajaran. kemampuan dan latar belakang guru dalam melaksanakan metode ini cukup mempuni karena sebagaian besar guru memiliki pengalaman pengajaran. Kemampuan siswa dalam melaksanakan pembelajan ini sangat kurang dikarenakan latar dan kemampuan siswa yang herogen. Keadaan dalam proses belajar minim sekali mengingat lokasi masuk kategori zona merah sehingga ketercapaian dalam pelaksanaan metode pembelajaran sulit tercapai. Ketersedian alat atau sarana sangat minim sehingga ketercapaian dalam melaksanakan metode pembelajaran ini sangat minim. Jika digambarkan dalam diagram, maka akan tampak seperti berikut: 


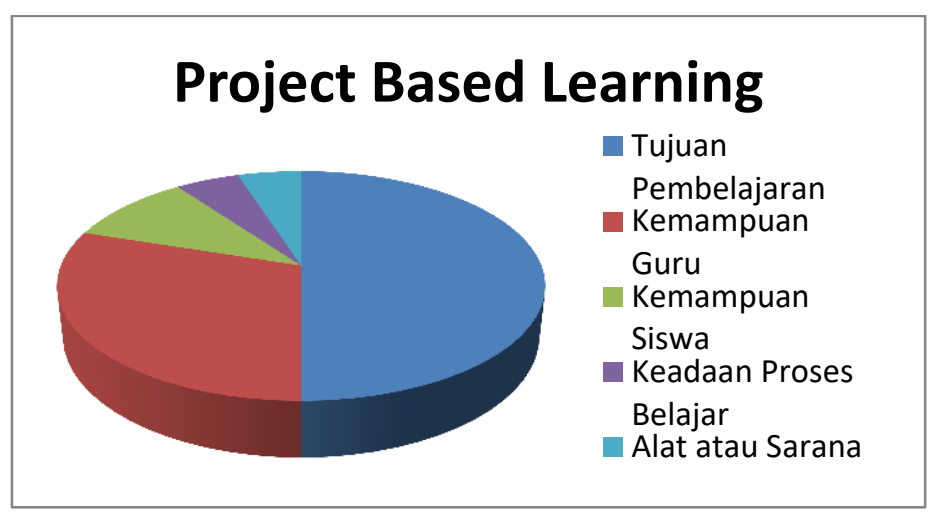

Diagram 1 : Pelaksanaan Project Based Learning

2. Daring Method

Metode ini merupakan metode pembelajaran dengan memanfaat media internet. Metode pembelajaran ini tidak mewajibkan siswa dan guru datang kesekolah. Sebanyak 36 responden memberikan pernyataan terkait pelaksanaan metode pembelajaran ini,bahwa tujuan pembelajaran bisa dicapai meskipun tidak terjadi kontak langsung antara guru dan murid dalam pembelajaran. Kemampuan guru dalam melaksanakan metode ini sedikit mengalami kendala hal ini dikarenakan sebagaian guru masih terbilang gagap teknologi. Kemampuan siswa dalam pelaksanaan metode pembelajaran ini sangat bagus, hal ini dapat dilihat dari kemampuan siswa dalam menggunakan teknologi informasi. Keadaan proses belajar sangat memungkin bahkan mengharuskan penggunaan metode pembelajaran daring, karena lokasi penelitian masuk dalam kategori zona kuning. Alat atau sarana yang digunakan dalam pelaksanaan metode ini relatif sedang karena sebagaian besar guru dan murid memilikinya seperti handphone. Jika digambarkan dalam bentuk diagram maka akan tampak seperti berikut ini.

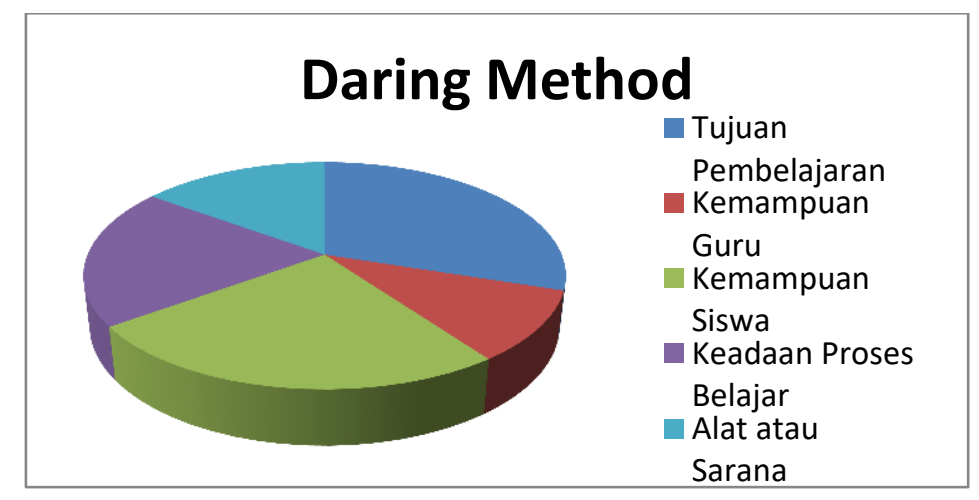

Diagram 2 : Pelaksanaan Daring Method

3. Luring Method

Metode pembelajaran ini dilakukan secara tatap muka langsung dengan memperhatikan protokol kesehatan. Dalam melaksanakan metode ini, siswa diajar secara bergantian atau bergiliran (shift model). Dari 36 responden memberikan pernyataan bahwa penggunaan metode pembelajaran ini, sangat besar akan tercapainya tujuan pembelajaran yang telah ditentukan. Kemampuan guru dalam melaksanakan metode ini, tidak diragukan lagi 
mengingat sebelum terjadi pandemi ini sering menggunakan metode ini. Kemampuan siswa dalam pelaksanaan metode ini sangat besar hal ini terlihat dari kebiasaan sebelum pandemi. Keaadaan proses belajar sangat minim hal ini dikarenakan lokasi berada dalam zona kuning yang memungkinkan menjadi zona merah. Alat atau sarana sangat menunjang mengingat pembelajaran tatap muka dilaksanakan lingkungan sekolah. Perhatikan diagram berikut ini.

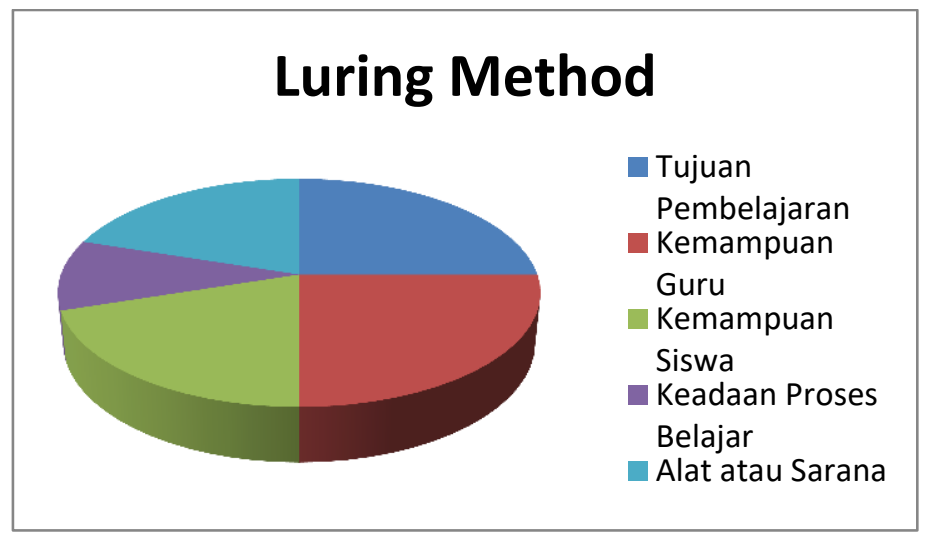

Diagram 3 : Pelaksanaan Luring Method

\section{Home Visit Method}

Home visit methode merupakan salah satu opsi metode pembelajaran yang dilakukan di masa new normal. Metode ini sangat mirip dengan home scholing. Pengajar datang ke rumah (visit home) siswa dalam waktu tertentu. Dari 36 responden memberikan pernyataan bahwa minimnya akan ketercapaian tujuan pembelajaran. Kemampuan Guru dalam melaksanaan metode ini dalam kategori sedang mengingat guru dalam melakukan metode ini terkendala umur. Kemampuan siswa dalam metode ini cukup besar hal ini dikarenakan siswa hanya menunggu guru dirumah. Keadaan proses belajar sangat besar hal ini dikarenan masa new normal. Alat atau sarana sangat minim mengingat pembelajaran dilaksanakan di rumah masing-masing siswa. Hal ini, dapat dilihat pada diagram dibawah ini.

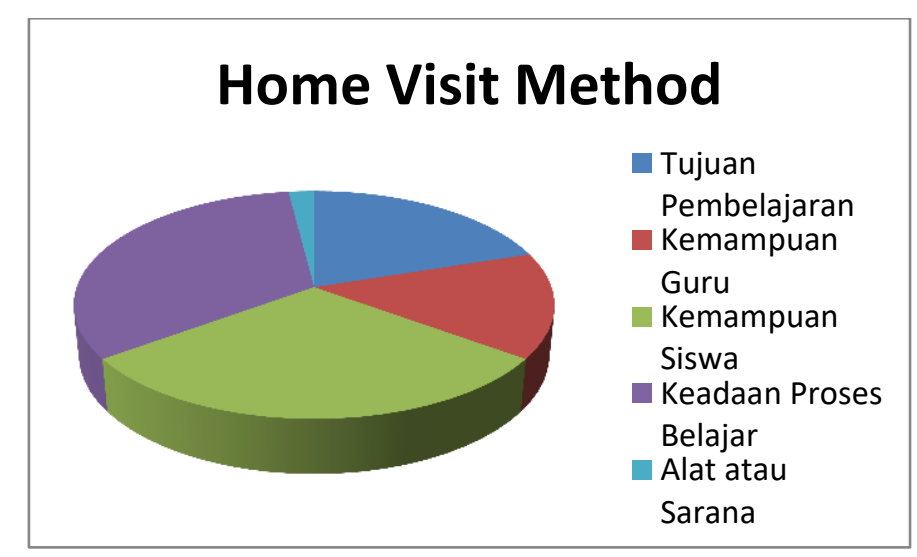

Diagram 4: Pelaksanaan Home Visit Method

5. Blended Learning 
Metode pembelajaran ini merupakan metode yang menggunakan dua pendekatan sekaligus. Dengan kata lain metode ini menggunakan sistem daring sekaligus tatap muka melalui video converence. Dari 36 responden memberikan pernyataan bahwa tujuan pembelajaran sangat tercapai. Kemampuan guru dalam melaksanakan metode ini berada dalam kategori cukup. Kemampuan siswa dalam pelaksanaan metode ini juga berada dalam kategori cukup. Keadaan proses belajar juga sangat besar mengingat kondisi sekarang masing masa new normal. Alat dan sarana sangat beragam dalam melaksanakan metode pembelajaran ini,yaitu: handphone, PC, aplikasi-aplikasi online. Jika digambarkan dalam diagram akan tampak seperti ini.

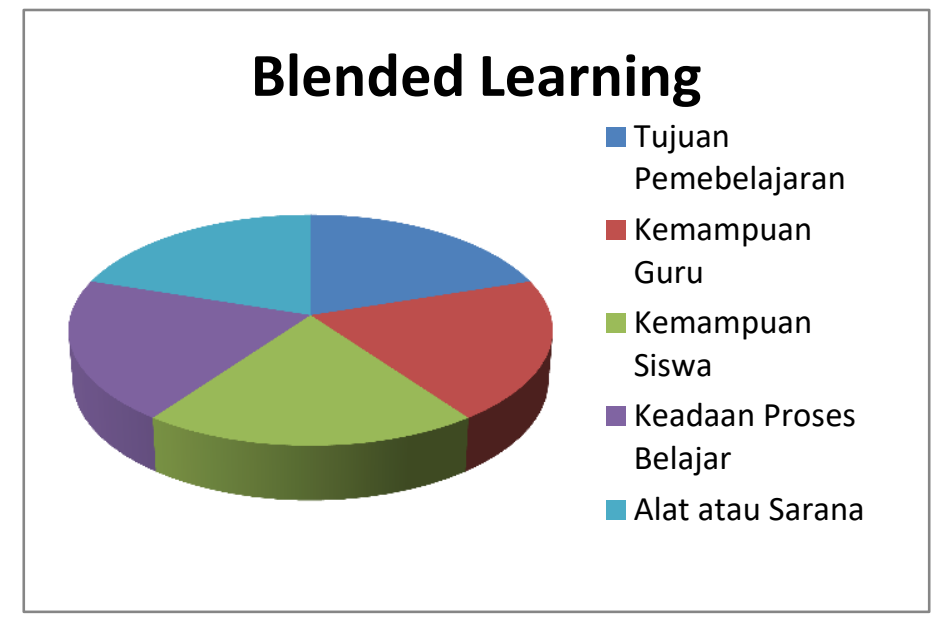

Diagram 5 : Pelaksanaan Blended Learning

Penggunaan metode pembelajaran harus betul-betul mempertimbangkan faktor-faktor di atas. Karena dalam kenyataannya tidak ada metode pembelajaran yang baik, yang ada hanya metode yang tepat dalam penggunaanya sehingga metode tersebut menjadi efektivitas dalam mencapai tujuan pembelajaran. oleh sebab itu keterampilan guru dalam dalam memilih dan menggunakan metode-metode dalam pembelajaran sangat dibutuhkan. Hal ini tentunya demi keberlangsungan proses pembelajaran terlebih dalam masa new normal seperti sekarang ini.

\section{SIMPULAN}

Simpulan yang dapat diambil dari uraian di atas, bahwa tidak semua metode pembelajaran efektif digunakan dalam proses pembelajaran, terlebih pada era new normal seperti sekarang ini. Pemilihan metode pembelajaran yang tetap akan memberikan permbelajaran yang efektif. Adapun opsi yang dapat dilakukan oleh guru dalam pembelajaran di era normal ini adalah dengan menggunakan metode blended learning. Tidak menutup kemungkinan metode daring, luring, dan project based learning dapat dilaksanakan dengan maksimal sesuai dengan situasi dan kondisi.

\section{DAFTAR PUSTAKA}

Bahri, S., \& Arafah, N. (2020). Analisis Manajemen Sdm Dalam Mengembangkan Strategi Pembelajaran Di Era New Normal. Interdisciplinary Journal of Islamic Education, 1(1), 20-40. Retrieved from https://scholar.google.co.id/scholar?start=0\&q=manajemen+sekolah+di+era+pandemi\&hl $=\mathrm{id} \&$ as_sdt $=0,5$ 
Dewi, W. A. F. (2020). Dampak COVID-19 terhadap Implementasi Pembelajaran Daring di Sekolah Dasar. Edukatif: Jurnal Ilmu Pendidikan, 2(1), 55-61. https://doi.org/10.31004/edukatif.v2i1.89

Herdiansyah, H. (2010). Metodologi Penelitian Kualitatif untuk Ilmu-Ilmu Sosial. Jakarta Selatan: Salemba Humanika.

HM, M. A. (2019). Menciptakan Pembelajaran Efektif Melalui Hypnoteaching. Ekspose: Jurnal $\begin{array}{llll}\text { Penelitian Hukum Dan } & \end{array}$ https://doi.org/10.30863/ekspose.v16i2.106

https://sevima.com/6-metode-pembelajaran-paling-efektif-di-masa-pandemi-menurut-parapakar/

Indahningrum, R. putri. (2020). Adaptasi Metode Pembelajaran Melalui E-Learning Untuk Menghadapi Era New Normal. 2507(1), 1-9.

Irianto, Heru dan Bungin, B. (2001). Pokok-Pokok Penting Tentang Wawancara. Jakarta: PT Raja Grafindo Persada.

Jamaluddin, J. (2015). Pembelajaran Perspektif Islam. Bandung: PT Remaja Rosdakarya.

Rofiki, M. (2019). Urgensi Supervisi Akademik dalam Pengembangan Profesionalisme Guru di Era Industri 4.0. Indonesian Journal Pf Basic Education, 2(3), 502-514.

Sugiono, S. (2008). Metode Penelitian Pendidikan; Pendekatan Kuantitatif, Kualitatif, dan $R \& D$. Bandung: Alfabeta.

Ulfa, Maria., S. (2018). Terampil Memilih Dan Menggunakan Metode Pembelajaran. Suhuf, 30(1), 35-56.

Yusuf, B. B. (2017). Konsep Dan Indikator Pembelajaran Efektif. Jurnal Kajian Pembelajaran Dan Keilmuan, Vol. 1, pp. 13-20. 